研究資料

\title{
スポーツ集合的効力感尺度の改訂・邦訳と 構成概念妥当性の検討
}

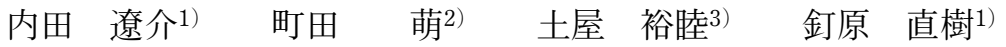

Ryosuke Uchida ${ }^{1}$, Moe Machida ${ }^{2}$, Hironobu Tsuchiya ${ }^{3}$ and Naoki Kugihara ${ }^{1}$ : Revision and Japanese translation of the Collective Efficacy Questionnaire for Sports: Test of its construct validity. Japan J. Phys. Educ. Hlth. Sport Sci. 59: 841-854, December, 2014

\begin{abstract}
Collective efficacy has been identified as a critical determinant of team success in sport. Many studies in sport psychology have focused on the relationships between collective efficacy and psychological variables or outcomes of interest. Although an increasing number of studies on collective efficacy have been conducted in Japan, greater attention should be given to refining the methodology for assessing the construct of collective efficacy. The purposes of this study were to confirm the factor structure and establish construct validity of the Japanese translated version of the Collective Efficacy Questionnaire for Sports (J-CEQS) with revisions to its original version (Short et al., 2005). The participants were 1244 athletes from 48 teams. We conducted a confirmatory factor analysis and found that the J-CEQS showed the same multidimensional factor structure as Short's original questionnaire. To test the construct validity of the J-CEQS, we examined correlations among its subscale scores with the Group Environment Questionnaire (GEQ, Carron et al., 1985). All the J-CEQS subscales were significantly correlated with the group integration-task subscales. The unity subscale of the J-CEQS was also significantly correlated with all the GEQ subscales. These correlations were similar to those shown in previous studies (Martinez et al., 2011; Short et al., 2005). The present findings provide preliminary support for the utility of the J-CEQS as a measure for assessing collective efficacy in sport teams. We discuss recommendations for future studies using the J-CEQS.
\end{abstract}

Key words : confiidence, factor analysis, sport group キーワード：自信，因子分析，スポーツ集団

\section{I 問 題 提 起}

勝利を求めるスポーツ集団に抢いて, 成功裏に 集団パフォーマンスを発揮することは重要な課題 である.この課題に対して, スポーツ心理学領域 では従来から集団凝集性やリーダーシップなど様
々な観点から検討されてきた。なかでも, Bandura（1982）によって提唱された集合的効力感 (collective efficacy) 注1) は2000年代以降, スポー ツ集団の集団パフォーマンスを説明する有力な概 念として着目されつつある.

集合的効力感とは自己効力感 (self-efficacy) の概念を集団レベルにまで拡張した概念であり,

1. Graduate School of Human Sciences, Osaka University 1-2 Yamadaoka, Suita, Osaka 565-0871

2. School of Health and Sports Science, Juntendo University

1-1 Hiragagakuendai, Inzai, Chiba 270-1695

3. Graduate School of Sport and Exercise Sciences, Osaka University of Health and Sport Sciences 1-1 Asashirodai, Kumatori, Sennan, Osaka 590-0496 Corresponding author uchida@hus.osaka-u.ac.jp 
「あるレベルに到達するため必要な一連の行動を 体系化し，実行する統合的な能力に関する集団で 共有された信念」（Bandura, 1997, p. 477）と定 義される，これまで学級集団や企業集団など様々 な集団を対象に幅広く実証研究が積み重ねられて きて抢り，それらの研究をメタ分析によって統合 した結果によれば集合的効力感と集団パフォーマ ンスには正の関連性 $(\rho=.41)$ が認められること が報告されている（Gully et al., 2002）。また，ス ポーツ集団を対象とした実証研究においても，や はり正の関連性が確認されることが記述レビュー によって確認されている（内田ほか，2011）。

わが国においても集合的効力感と近接する概 念，あるいは行動指標との関連性を検討した実証 研究が盛んになされつつある，その一方で，集合 的効力感を測定する方法論についてはそれほど注 意が向けられていない，本研究では集合的効力感 を測定する際の方法上の留意点や，わが国におい て作成されてきた集合的効力感尺度（付録）の修 正すべき点を踏まえつつ，将来的に実施されるス ポーツ集団を対象とした集合的効力感研究におい て適切であると考えられる尺度を作成することを 目的とした。

\section{集合的効力感の測定方法}

集合的効力感は課題特定的かつ状況特定的な概 念であるため，集合的効力感を測定する際に使用 される尺度は各々研究対象となる領域や集団に応 じて大きく内容が異なってきた，ただし，測定す る際の尺度の構成法（回答形式や教示）に関して はある程度のガイドラインが示されている．例え ば，概念の提唱者である Bandura（2006）は集

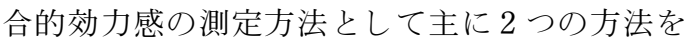
提案している. 1つは，集団の課題に関する役割 を遂行するための「自己の能力」に対して内集団 成員 1 人 1 人に評価させて集計（平均化）する 方法と，もう 1 つは「集団の能力」に対する内 集団成員 1 人 1 人の評価を集計する方法であ る.この 2 つ測定方法は課題達成に必要とな る相互依存的な努力の程度に応じて使い分けるこ とが推奨されている。
スポーツ集団を対象とした集合的効力感の測定 方法については Myers and Feltz (2007)の概説 に扔いて特に詳しく論じられている，彼らはス ポーツ集団を対象になされてきた過去の研究にお いて少なくとも 4 つの方法が存在すると述べて いる注2)。具体的には，(1)「自己の能力」に対し てどの程度自信があるか (i.e., 自己効力感)を 内集団成員 1 人 1 人に評価させた後で集計する 自己効力感の合算に基づく評定法, (2)「集団の能 力」に対して自分自身がどの程度自信があるかを 内集団成員 1 人 1 人に判断させた後で集計する 個人評定法, (3)「集団の能力」に対して集団全体 としてどの程度自信があるかを内集団成員 1 人 1 人に判断させた後で集計する集団評定法, (4)「集 団の能力」に対して内集団成員全員の議論によっ てどの程度自信があるかを判断させるディスカッ ション評定法の 4 つである.

それぞれの特徵として，まず，自己効力感の合 算に基づく評定法は相互依存的な努力をあまり必 要としない競技種目に拈いて集団パフォーマンス を予測するのに有効な測定手法とされる。ただ し，相互依存的な努力を必要とする競技種目にお いては統計的に有意ではないものの個人評定法に 劣ることが報告されている（Feltz and Lirgg, 1998)。次に，個人評定法と集団評定法は教示部 分の違いだけであって（個人評定法は“rate your confidence, ‥”，集団評定法は “rate your team’s confidence, $\cdots ”) ， そ れ に$ 続く具体的な尺度項目 は同一の内容で構成される. 個人評定法は Bandura（1997）の概念定義を重視する研究者に好 まれる一方で, 集団評定法はZaccaro et al. （1995）の集団内に打ける協同的側面に重点を打 く研究者に好まれる. 最後に, ディスカッション 評定法は集団内の説得の影響によって集合的効力 感の評価が歪められる可能性があるためにあまり 推奨されていない (Bandura, 2000). Myers and Feltz（2007）は最終的にこれまでに行われてきた 実証研究の多くが Bandura（1997）の概念定義 に依って立つ個人評定法に基づいて測定されてい ること, 個人評定法の方が集団評定法よりも回答 の容易さ（accessibility）という点で優れている 
ことなどから最終的に個人評定法の使用を推奨し ている.

わが国に抢いてもスポーツ集団の集合的効力感 を測定するために，幾つかの尺度が作成されてい る (付録).なかでも英語圏で作成された尺度を 邦訳して使用するにあたって, Short et al. (2005)のスポーツ集合的効力感尺度 (Collective Efficacy Questionnaire for Sports）が最も引用さ れている（河津ほか，2012; 永尾·杉山，2013; 芹澤ほか，2008）。この尺度は作成段階から様々 なスポーツ種目にわたって集合的効力感を測定す ることを意図して作成されており, 特定の競技種 目に特化して作成された他の集合的効力感尺度と は異なっている. 作成手続きについても詳細に記 述されており，第1フェーズ（尺度項目リスト の作成と探索的因子分析), 第 2 フェーズ（検証 的因子分析による尺度項目数の決定), 第 3 フ エーズ（構成概念妥当性の検討）のそれぞれ独立 した 3 度の調査を経て尺度が作成されている。 さらに, 作成過程においてコーチや学生アスリー ト, スポーツ心理学の専門家, 大学院生から尺度 項目の内容について意見を複数回求めるフォーカ ス・グループ法を使用して抢り，尺度項目の内容 的妥当性について十分に検討されている. 例え ば，第 1 フェーズの尺度項目を選定する過程に おいて統計学的基準に満たなかった尺度項目があ ったとしても，フォーカス・グループ法によって 採用すべきと判断された場合は第 2 フェーズに 残す一方で, 統計学的基準を満たしていても尺度 項目の内容が圥長であると判断された場合は第 1 フェーズで除外するなど, 単に統計学的基準に依 拠することなく作成されている，また，集合的効 力感と肯定的な関連性を持つ概念と指摘 (Zaccaro et al., 1995）されている集団凝集性との相関 行列を求めて構成概念妥当性の検討を行ってい る. その結果として, 彼女らは「能力」(ability), 「努力」(effort), 「忍耐力」(persistence), 「準備 力」 (preparation), 「結束力」 (unity) の 5 つの 下位尺度で構成される合計 20 項目（各下位尺度 に 4 項目）の尺度を作成した.

\section{集合的効力感尺度に関する今日的課題}

Short et al. (2005)の作成したスポーツ集合的 効力感尺度は様々なスポーツ集団の集合的効力感 を測定できるという点で極めて有用性の高い尺度 である。しかしながら, Short et al. (2005) の作 成した原版尺度やそれを邦訳した尺度には，より 最近の集合的効力感の測定方法から考えた場合に 幾つかの修正すべき点を抱えている.

第 1 に教示の方法が挙げられる. Short et al. （2005）の作成した原版尺度は集合的効力感を測 定する際の教示として“rate your team’s confidence, in terms of the upcoming game or competition, that your team has the ability to...” と提示し ており, 前述の Myers and Feltz (2007) で論じ られている測定方法の分類から解釈すると集団評 定法に分類される. そのため, 本尺度は従来の研 究の多くが採用し, かつ将来的な研究においても 推奖されている個人評定法による測定方法を採用 していない，集団評定法による集合的効力感の測 定值と個人評定法による集合的効力感の測定值の 間に統計的な違いは認められていないものの (Short et al., 2002), 概念的な観点からみた場合 に両者の間には看過できない隔たりが存在する. Short et al. (2005) の原版尺度で採用されている 集団評定法は「集団の能力」に対する集団全体の 自信を内集団成員 1 人 1 人に推測させていると いう点で個々人の信念に帰属され得るものではな い. そのため, 集団評定法において内集団成員は 集団全体の集合的効力感を推定するための情報提 供者（informant）として位置づけられている. それに対して，個人評定法は「集団の能力」に対 する自信の程度を内集団成員 1 人 1 人に評価さ せているという点で個々人に帰属可能な信念を測 定して抢り，内集団成員 1 人 1 人の集合的効力 感に着目した検討が可能である.

第 2 に尺度項目の提示順が挙げられる.これ までのところ Short et al. (2005) の作成した原版 尺度を邦訳して使用した研究論文（河津ほか, 2012 ; 永尾·杉山，2013；芹澤ほか，2008）で は, いずれも探索的因子分析の結果, 原版尺度と 同様の因子構造が再現されず尺度項目の幾つかを 
削除したうえで独自の因子構造を報告している. この結果に対しては大きく分けて $2 つ の$ 解釈が 考えられる. 1 つは集合的効力感の構成概念が文 化的な背景などによって欧米と異なっていたため に因子構造が再現されなかったという解釈，もう 1 つは測定する際に使用した質問紙のレイアウト やデータの分析手続きといった方法に起因する影 響によって因子構造が再現されなかったとする解 釈の 2 つである。これまでの研究では主に前者 の観点から因子構造が再現されなかった理由につ いて論じられていたが，本研究では特に後者の観 点，とりわけ尺度項目の提示順序が無作為に提示 されていたという点から解釈する. Podsakoff et al. (2003) は尺度項目の提示順序を無作為化する 方法は心理尺度において一般的な方法であり，測 定方法に起因するバイアスを減少させるのに有効 な方法と述べている。しかしながら，このような 方法を用いた際の問題点として，異なった概念間 の相関を高めると同時に概念内の相関を減少させ ると指摘している。つまり, Short et al. (2005) の提示順序に従って無作為に尺度項目を提示した 場合に, Podsakoff et al. (2003) の指摘するよう な概念間の相関を増加させると同時に概念内の相 関を減少させ，その結果として因子構造が再現さ れなかった可能性が考えられる. Short et al. （2005）の尺度項目は作成段階から先行研究の尺 度項目を参考にするだけでなく, フォーカス・グ ループ法によってコーチや学生アスリートの意見 を尺度項目へ反映するなど，尺度項目について内 容的な観点から十分に検討されている。このよう な綿密な調査手続きがとられていることを考慮す るのであれば, 単に統計学的基準にそぐわなかっ たことを理由に尺度項目を除外して新たな因子構 造を仮定するのは性急である，原版尺度の内容的 妥当性を考慮するのであれば尺度項目の提示順を 下位尺度毎に順序立てて提示する方が回答の容易 さを高め，結果として Short et al.（2005）の意図 した多次元的な 5 因子構造が再現される可能性 が高められる。

第 3 に回答形式の問題が挙げられる. 効力感 を測定する際にBandura（2006）は単極性 （unipolar）かつ11件法の回答形式で尺度を構成 することを推奨しており，“cannot do at all” (0 点), “moderately certain can do” (50点), “highly certain can do”（100点）の10点間隔で強 度が増加する11件法の回答形式を例示している。 Short et al. (2005) の原版尺度は基本的に上記の 推奨に則って, “not at all confident” (0 点) か ら“extremely confident”（10点）まで 1 点間隔 で強度が増加する単極性かつ11件法の回答形式 で構成されている。しかしながら， Myers and Feltz（2007）は一般的に使用されてきた11件法の 回答形式についてカテゴリー数を減らすことを推 奨しており，それによって尺度の安定性と正確性 が増すと述べている。また，Short et al. (2005) の原版尺度では回答形式の中点上に Bandura （2006）の例示する “moderately certain can do" （50点）に該当する説明が付記されていない。中 点上に説明が付記されていない場合, 調查対象者 に「どちらでもない」と解釈されることで単極性 尺度として成立しない可能性が考えられる。 Bandura（2006）のガイドラインに則って中点上 に説明を付記することでこのような誤った解釈を 未然に防ぐことが可能となり，より正確に調査対 象者の集合的効力感を測定することが可能になる.

そこで, 本研究では Short et al. (2005) の作成 したスポーツ集合的効力感尺度を邦訳するにあた って，上記で指摘した最近の集合的効力感研究の 考え方に則った修正を施し, 日本語版スポーツ集 合的効力感尺度を作成することを目的とした。 ま た，作成した尺度の構成概念妥当性については， Short et al.（2005）の論文中で報告されている集 団凝集性との相関行列を確認することで検討した.

\section{II 方法}

\section{調査時期と調査対象者}

本調査は大阪体育大学倫理審査委員会の承認 （承認番号12-8）を得て実施した。調査を実施し た時期は 2012 年 6 月から 2013 年 3 月であった. 質問紙調査はあらかじめ研究協力者に研究内容を 説明し，同意が得られた場合にの久質問紙を郵送 
した，研究協力者には試合 1 週間前以内に質問 紙調査を実施するように依頼した。また，質問紙 調查終了後は速やかに返送するように依頼した. 回答済みの質問紙が研究協力者から返送され, 正 しくデータ収集が行われているのを確認してから 速やかに調査結果のフィードバックと謝礼 （2000円）を送付した.

上記手続きのもと，48チーム 1338 名の回答を 得た. 最終的な調査対象者は欠損值を有する調査 対象者を除いた1244名（男性921名，女性323名） であった（有効回答率 $92.97 \%)$. 調査対象者が行 っていたスポーツ種目はサッカー $(n=397)$, ラ グビー $(n=322)$, バスケットボール $(n=107)$, ソフトテニス $(n=82)$, ソフトボール $(n=51)$, 硬式野球 $(n=48)$, バレーボール $(n=48)$, フ ィールドホッケー $(n=40)$, アメリカンフット ボール $(n=29)$, ハンドボール $(n=26)$, 剣道 $(n=26)$, フットサル $(n=22)$, テニス $(n=17)$, バトントワリング $(n=11)$, ラクロス $(n=10)$, なぎなた $(n=8)$ の16種目であった。調査対象 者の平均年齢は 19.61 歳 \pm 3.91 歳, 平均所属年数 は2.44年 \pm 2.13 年であった。

\section{質問紙の構成}

質問紙はフェイスシート（氏名，性別，役割な ぞ), 集合的効力感の尺度, 集団凝集性の尺度で 構成した。

\section{1）集合的効力感}

集合的効力感の測定には Short et al. (2005)の スポーツ集合的効力感尺度の 20 項目を邦訳して 使用した。この尺度は「能力」(ability),「努力」 (effort),「忍耐力」(persistence),「準備力」 (preparation),「結束力」(unity) の 5 因子 20 項 目によって構成されている. 原版尺度を邦訳する に際して以下の修正を行った。なお，日本語版ス ポーツ集合的効力感尺度を作成するにあたって原 著者の S. Short 博士より作成許可を得た.

第 1 に, 教示部分を集団評定法から個人評定 法に変更した。原版尺度の教示部分は “rate your team's confidence, in terms of the upcoming game or competition, that your team has the ability to $\cdots$ ”と示されていたが，本研究では特に“rate your team's confidence, …”の部分を“rate your confidence, ‥”に变更した. 最終的に日本語に適した 表現に修正した結果,「現時点での『代表チーム の能力』についてあなたはどの程度自信がありま すか? 目前の試合をイメージしながら『全く自 信がない』から『かなり自信がある』までの 5 段階で回答してください。」と教示することにし た. 第 2 に, 尺度項目の提示順序を無作為では なく下位尺度毎に順序立てて提示した. 具体的に は,「能力」に関する尺度項目を 1 番から 4 番に, 「努力」に関する尺度項目を 5 番から 8 番に， 「忍耐力」に関する尺度項目を 9 番から 12 番に, 「準備力」に関する尺度項目を13番から16番に， 「結束力」に関する尺度項目を 17 番から 20 番に配 置した．第 3 に, 11件法の回答形式を 5 件法の 回答形式に変更し, 回答形式の中点上に新たに 「やや自信がある」(3 点)を追加した.

原版尺度を英語から日本語へ翻訳するに際し て, 英語圏でスポーツ心理学の博士号を取得した スポーツ心理学の研究者 1 名と実際にスポーツ チームの指導に携わるコーチ 1 名を交えて尺度 項目の内容的妥当性について検討した. 調查対象 者には「全く自信がない」(1点),「やや自信が ある」(3 点),「かなり自信がある」（5 点）の 5 件法で回答を求めた.

\section{2）集団凝集性}

集団凝集性の測定には集団環境質問票（group environment questionnaire, Carron et al., 1985; Widmeyer et al., 1985）を使用した. 尺度項目の 邦訳については織田ほか（2007）の表 1 に記載 されている邦訳を一部修正して使用した。この尺 度は GI-T (group integration-task, 課題的側面 に対する集団の一体感), GI-S (group integration-social, 社会的側面に対する集団の一体 感), ATG-T (individual attractions to grouptask, 課題的側面に対する個人的魅力), ATG-S (individual attractions to group-social, 社会的側 面に対する個人的魅力）の 4 因子 18 項目によっ て構成されている. 調査対象者は「全く違う」 （1点）から「全くその通りだ」（9点）の9件法 
によって回答した.

\section{分析方法}

\section{1）因子構造の検討}

因子構造の検討には検証的因子分析を使用し た. パス係数（因子負荷）の有意性は $5 \%$ 水準 をもって有意とした。モデルの適合度指標につい ては GFI (goodness of fit index), AGFI (adjusted goodness of fit index), CFI (comparative fit index), RMSEA (root mean square error of approximation）の 4 種類の適合度指標を参照し た．信頼性の検討にはクロンバックの $\alpha$ 係数を 用いた。

\section{2）構成概念妥当性の検討}

Short et al.（2005）はスポーツ集合的効力感尺 度と集団環境質問票の下位尺度間の相関行列を用 いて構成概念妥当性を検討している．本研究にお いても同様の点を検討することで日本語版スポー ツ集合的効力感尺度の構成概念妥当性を検討した.

第 1 に，日本語版スポーツ集合的効力感尺度 と集団環境質問票の相関係数について確認した. 集合的効力感と集団凝集性はいずれも集団の特徵 を表す概念であることから，両概念間の全ての相 関係数の值とその有意性を確認することで併存的 妥当性の根拠とした。第 2 に，収束的妥当性の 根拠として日本語版スポーツ集合的効力感尺度の 5 つの下位尺度間の相関係数を確認した．同時に， 5 つの下位尺度間の相関係数が，5つの下位尺度 と集団環境質問票の下位尺度間の相関係数よりも 高いことを確認することで弁別的妥当性の根拠と した．第 3 に，日本語版スポーツ集合的効力感 尺度の全ての下位尺度と集団環境質問票の下位尺 度である GI-T との相関係数を確認した，GI-T は集団全体としての課題の取り組み方について客 観的に評価することを必要とするため，スポーツ 集合的効力感尺度の全ての下位尺度と相関が強く なると予測している（Short et al.，2005）。第 4 に，スポーツ集合的効力感尺度と課題凝集性 (ATG-T, GI-T)，社会凝集性（ATG-S, GI-S） に関する下位尺度との相関係数について確認した。 Short et al.（2005）は集合的効力感と社会凝集性
が関連するという根拠はないと述べている。 た, 河津ほか（2012）は課題凝集性の下位尺度 のほうが社会凝集性の下位尺度よりも集合的効力 感と強い相関関係（ATG-T >ATG-S, GI-T > GI-S）にあったことを報告している。第 5 に， 日本語版スポーツ集合的効力感尺度の「結束力」 と集団環境質問票の全ての下位尺度との相関係数 を確認した. Short et al. (2005) はスポーツ集合 的効力感尺度の「結束力」は集団凝集性と類似す る概念であることから，集団環境質問票の全ての 下位尺度と相関が強くなると予測している。

\section{III 結果}

\section{因子構造の検討}

\section{1） 日本語版スポーツ集合的効力感尺度}

尺度項目毎に平均值士標準偏差を求めた（表 1)。いずれの尺度項目に抢いても床効果, 天井 効果は認められなかった。 最尤法による検証的因 子分析の結果，すべてのパス係数（因子負荷）は $1 \%$ 水準で有意であった。モデルの適合度指標は $\mathrm{GFI}=.89, \mathrm{AGFI}=.86, \mathrm{CFI}=.93, \mathrm{RMSEA}=.08$ で あった．各因子の信頼性を検討するためにクロン バックの $\alpha$ 係数を算出した. その結果， $\alpha=.83$ か ら.91であった。

\section{2）集団環境質問票}

各尺度項目の平均值士標準偏差を確認したとこ ろ，幾つかの尺度項目に抢いて天井効果が認めら れた（表 2)。しかし，いずれの尺度項目におい ても十分な分散を有していることから除外しなか った．最尤法による検証的因子分析の結果，すべ てのパス係数（因子負荷）は $1 \%$ 水準で有意で あった。モデルの適合度指標は $\mathrm{GFI}=.89, \mathrm{AGFI}$ $=.86, \mathrm{CFI}=.89, \mathrm{RMSEA}=.08$ であった。 また， 各下位尺度の信頼性を検討するためにクロンバッ クの $\alpha$ 係数を算出した。 その結果， $\alpha=.64$ か ら.84であった。

\section{構成概念妥当性の検討}

日本語版スポーツ集合的効力感尺度と集団環境 質問票の下位尺度間の相関行列を求めた（表 3- 
表 1 日本語版スポーツ集合的効力感尺度の因子構造

\begin{tabular}{|c|c|c|c|c|c|c|}
\hline 第 I 因子 能力 & I & II & III & $\mathrm{N}$ & $\mathrm{V}$ & $M \pm S D$ \\
\hline 2 相手チームよりも実力を示す能力. & .88 & & & & & $3.48 \pm 1.00$ \\
\hline 4 相手チームよりも優れたパフォーマンスをする能力. & .86 & & & & & $3.41 \pm 1.04$ \\
\hline 1 相手チームに勝つ能力. & .84 & & & & & $3.66 \pm 1.03$ \\
\hline 3 相手チームよりも技術的に高いレベルのプレーをする能力. & .81 & & & & & $3.33 \pm 1.08$ \\
\hline \multicolumn{7}{|l|}{ 第II因子 努力 } \\
\hline 7 熱意を見せる能力. & & .78 & & & & $3.87 \pm 1.03$ \\
\hline 6 チームが持っている力を出し切る能力. & & .76 & & & & $3.48 \pm 0.99$ \\
\hline 8 心理的な動摇に打ち勝つ能力. & & .76 & & & & $3.26 \pm 1.06$ \\
\hline 5 努力を惜しまずプレーをする能力. & & .73 & & & & $3.77 \pm 0.98$ \\
\hline \multicolumn{7}{|l|}{ 第而因子 忍耐力 } \\
\hline 10 困難な状況であってももちこたえる能力. & & & .83 & & & $3.32 \pm 1.06$ \\
\hline 9 プレッシャーのかかった場面でも実力を発揮する能力. & & & .80 & & & $3.27 \pm 1.04$ \\
\hline 11 チャンスがほとんど無い時でも試合に集中する能力. & & & .79 & & & $3.42 \pm 1.07$ \\
\hline 12 主力メンバーがいなくてもなんとか良いプレーをする能力. & & & .65 & & & $3.42 \pm 1.07$ \\
\hline \multicolumn{7}{|l|}{ 第 $\mathbb{N}$ 因子 準備力 } \\
\hline 14 試合にむけて心理的なコンディションを整える能力. & & & & .82 & & $3.49 \pm 0.99$ \\
\hline 13 試合にむけて準備をする能力. & & & & .81 & & $3.58 \pm 0.98$ \\
\hline 15 試合にむけて身体的なコンディションを整える能力. & & & & .78 & & $3.56 \pm 0.97$ \\
\hline 16 優れた戦術を計画する能力. & & & & .58 & & $3.25 \pm 1.05$ \\
\hline \multicolumn{7}{|l|}{ 第 $\mathrm{V}$ 因子 結束力 } \\
\hline 18 一致団結する能力. & & & & & .81 & $3.76 \pm 1.04$ \\
\hline 20 メンバー間で効果的なコミュニケーションをとる能力. & & & & & .77 & $3.68 \pm 1.00$ \\
\hline 19 常に前向きな態度でいる能力. & & & & & .77 & $3.66 \pm 1.04$ \\
\hline \multirow{2}{*}{$\begin{array}{c}17 \text { メンバー間の言い争いを解決する能力. } \\
\text { 因子間相関 }\end{array}$} & & & & & .62 & $3.12 \pm 1.05$ \\
\hline & I & II & III & $\mathbb{N}$ & $\mathrm{V}$ & \\
\hline 第 I 因子 能力 & 1 & & & & & \\
\hline 第II因子 努力 & .68 & 1 & & & & \\
\hline 第而因子 忍耐力 & .74 & .87 & 1 & & & \\
\hline 第 $\mathrm{N}$ 因子 準備力 & .53 & .75 & .70 & 1 & & \\
\hline 第 V因子 結束力 & .56 & .74 & .67 & .71 & 1 & \\
\hline
\end{tabular}

a).その結果，すべての相関係数は $1 \%$ 水準で 有意であった. Short et al. (2005) はスポーツ集 合的効力感尺度の下位尺度間相関のほうが集団環 境質問票の下位尺度との相関係数よりも高值を示 したことを報告している（表 3-b）。本研究にお いても日本語版スポーツ集合的効力感尺度の下位 尺度間相関（ $r=.48$ - $74 ）$ のほうが集団環境質 問票の下位尺度との相関 $(r=.18-.55)$ よりも 概福高值を示した。したがって，日本語版スポー
ツ集合的効力感尺度の收束的妥当性と弁別的妥当 性は支持された. Short et al. (2005) はスポーツ 集合的効力感尺度の 5 つの下位尺度と集団環境 質問票の GI-T（課題的側面に対する集団の一体 感）の相関係数が $r=.37$ から .57であったことを 報告していたが，本研究に打いても $r=.32$ か ら.55と類似する範囲の值を示した。 また，河津 ほか（2012）は課題凝集性の下位尺度が社会凝 集性の下位尺度よりも集合的効力感と強い相関関 
表 2 集団凝集性尺度の因子構造

\begin{tabular}{|c|c|c|c|c|c|}
\hline 第 I 因子 ATG-S : 社会的側面に対する個人的魅力 & I & II & III & $\mathrm{N}$ & $M \pm S D$ \\
\hline 1 チームのメンバーとの付き合いは楽しい. & .70 & & & & $7.75 \pm 1.55$ \\
\hline $\begin{array}{l}7 \text { チーム以外の者との付き合いよりも, チームメンバーとの付き合い } \\
\text { のほうが楽しい. }\end{array}$ & .70 & & & & $6.72 \pm 1.99$ \\
\hline 3 シーズンが終わって, チームのメンバーと会わなくなると寂しい。 & .68 & & & & $6.56 \pm 2.24$ \\
\hline $\begin{array}{l}9 \text { このチームでの活動は自分が所属している集団の中でも最も大切な } \\
\text { 集団のひとつである. }\end{array}$ & .63 & & & & $7.86 \pm 1.64$ \\
\hline 5 親しい友人がチームの中に数人いる. & .62 & & & & $7.74 \pm 1.77$ \\
\hline \multicolumn{6}{|l|}{ 第 II 因子 ATG-T : 課題的側面に対する個人的魅力 } \\
\hline 8 このチームのプレースタイルが気に入っている. & & .70 & & & $6.57 \pm 2.00$ \\
\hline $\begin{array}{l}6 \text { このチームは自分のパフォーマンスを伸ばす機会を十分に与えてく } \\
\text { れている. }\end{array}$ & & .67 & & & $6.94 \pm 1.99$ \\
\hline 4 チームが試合に勝とうとする意欲に満足している. & & .65 & & & $6.53 \pm 2.09$ \\
\hline 2 試合のとき, 自分の出場時間に満足している. & & .30 & & & $5.62 \pm 2.82$ \\
\hline \multicolumn{6}{|l|}{ 第吕因子 GI-T : 課題的側面に対する集団の一体感 } \\
\hline 10 われわれのチームは一致団結して目標を達成しようとしている. & & & .75 & & $7.15 \pm 1.84$ \\
\hline 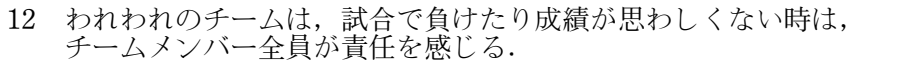 & & & .73 & & $6.29 \pm 2.07$ \\
\hline 14 われわれのチームのメンバーは, チーム目標が一致している. & & & .72 & & $7.32 \pm 1.86$ \\
\hline $\begin{array}{c}16 \text { われわれのチ一㕕は, 練習中にうまくくできないメンバーがいると } \\
\text { きメンバー全員でサポートす. }\end{array}$ & & & .71 & & $6.16 \pm 2.01$ \\
\hline $\begin{aligned} 18 \text { われわれのチームのメンバーは，試合や練習のとき，それぞれの役 } \\
\text { 割や責任などについて遠慮なく話し合う. }\end{aligned}$ & & & 69 & & $6.47 \pm 1.98$ \\
\hline \multicolumn{6}{|l|}{ 第IV因子 GI-S：社会的側面に対する集団の一体感 } \\
\hline $\begin{array}{l}15 \text { われわれのチームは, シーズンオフの時でもチームのメンバーと一 } \\
\text { 緒に過ごしたいと思っている. }\end{array}$ & & & & .77 & $6.19 \pm 2.05$ \\
\hline 17 われわれのチームは，試合や練習以外の時でも仲が良い。 & & & & .76 & $7.50 \pm 1.69$ \\
\hline $\begin{array}{l}11 \text { われわれのチームは, それぞれ出かけるよりも, チームメンバーと } \\
\text { 一緒に出かけることを好む. }\end{array}$ & & & & .68 & $6.20 \pm 1.94$ \\
\hline $\begin{array}{l}13 \text { われわれのチームは，チームのメンバー同士でパーティ（飲み会· } \\
\text { 食事会など）をよくひらく. }\end{array}$ & & & & .55 & $5.79 \pm 2.32$ \\
\hline 因子間相関 & I & II & III & $\mathrm{N}$ & \\
\hline 第 I 因子 ATG-S & 1 & & & & \\
\hline 第II因子 ATG-T & .74 & 1 & & & \\
\hline 第而因子 GI-T & .60 & .85 & 1 & & \\
\hline 第 $\mathrm{N}$ 因子 $\mathrm{GI}-\mathrm{S}$ & .84 & .64 & .77 & 1 & \\
\hline
\end{tabular}

$\mathrm{GFI}=.89, \mathrm{AGFI}=.86, \mathrm{CFI}=.89, \mathrm{RMSEA}=.08$

係を示すことを報告していたが，本研究において も同様の関係性（ATG-T > ATG-S, GI-T > GIS）が確認された。最後に，日本語版スポーツ集 合的効力感尺度の「結束力」と集団環境質問票の 全ての下位尺度との相関係数を確認した。 その結 果, Short et al. (2005)の報告した相関係数 $(r$ $=.42$ - .57） と, 本研究において得られた相関係 数 $(r=.33$ - .55 $)$ は概ね類似する值を示した.
これらの結果については Short et al. (2005)の原 版尺度をスペイン語に翻訳した Martinez et al. (2011) の研究とも比較可能であり, 本研究にお いて得られた相関行列と類似する傾向が見て取れ る (表 3-c). 以上の結果から, 日本語版スポー ツ集合的効力感尺度と集団環境質問票は Short et al. (2005) の報告した相関行列と類似する相関行 列を示していると解釈できる。したがって，日本 
表 3-a 本研究において得られた集合的効力感と集団凝集性の相関行列

\begin{tabular}{|c|c|c|c|c|c|c|c|c|c|c|c|c|c|c|}
\hline & & 1 & 2 & 3 & 4 & 5 & 6 & 7 & 8 & 9 & 10 & $M \pm S D$ & 範囲 & $\alpha$ 係数 \\
\hline \multirow{6}{*}{$\begin{array}{l}\text { 集 } \\
\text { 合 } \\
\text { 的 } \\
\text { 感 } \\
\text { 効 }\end{array}$} & 1 能力 & 1 & & & & & & & & & & $3.47 \pm 0.92$ & $1.00-5.00$ & .91 \\
\hline & 2 努力 & .59 & 1 & & & & & & & & & $3.59 \pm 0.84$ & $1.25-5.00$ & .84 \\
\hline & 3 忍耐力 & .66 & .74 & 1 & & & & & & & & $3.36 \pm 0.88$ & $1.00-5.00$ & .85 \\
\hline & 4 準備力 & .51 & .64 & .63 & 1 & & & & & & & $3.47 \pm 0.81$ & $1.00-5.00$ & .83 \\
\hline & 5 結束力 & .48 & .61 & .57 & .62 & 1 & & & & & & $3.56 \pm 0.84$ & $1.00-5.00$ & .83 \\
\hline & 6 合計得点 & .79 & .86 & .87 & .82 & .79 & 1 & & & & & $3.49 \pm 0.71$ & $1.30-5.00$ & .94 \\
\hline \multirow{4}{*}{$\begin{array}{l}\text { 集 } \\
\text { 団 } \\
\text { 㠜 } \\
\text { 性 }\end{array}$} & 7 ATG-T & .28 & .36 & .32 & .30 & .40 & .40 & 1 & & & & $6.42 \pm 1.56$ & $1.00-9.00$ & .64 \\
\hline & 8 ATG-S & .21 & .25 & .21 & .18 & .33 & .29 & .53 & 1 & & & $7.33 \pm 1.37$ & $1.00-9.00$ & .79 \\
\hline & $9 \mathrm{GI}-\mathrm{T}$ & .32 & .47 & .38 & .41 & .55 & .51 & .60 & .49 & 1 & & $6.68 \pm 1.53$ & $1.00-9.00$ & .84 \\
\hline & 10 GI-S & .18 & .26 & .23 & .23 & .38 & .31 & .44 & .64 & .62 & 1 & $6.42 \pm 1.57$ & $1.00-9.00$ & .78 \\
\hline
\end{tabular}

表 3-b Short et al.（2005）で報告されている集合的効力感と集団凝集性の相関行列

\begin{tabular}{|c|c|c|c|c|c|c|c|c|c|c|c|c|c|c|}
\hline & & 1 & 2 & 3 & 4 & 5 & 6 & 7 & 8 & 9 & 10 & $M \pm S D$ & 範囲 & $\alpha$ 係数 \\
\hline \multirow{6}{*}{$\begin{array}{l}\text { 集 } \\
\text { 合 } \\
\text { 的 } \\
\text { 感 } \\
\end{array}$} & 1 能力 & 1 & & & & & & & & & & $7.22 \pm 1.48$ & $1.00-9.00$ & .91 \\
\hline & 2 努力 & .70 & 1 & & & & & & & & & $7.21 \pm 1.32$ & $2.25-9.00$ & .87 \\
\hline & 3 忍耐力 & .69 & .86 & 1 & & & & & & & & $7.04 \pm 1.21$ & $2.75-9.00$ & .81 \\
\hline & 4 準備力 & .76 & .87 & .80 & 1 & & & & & & & $7.09 \pm 1.40$ & $2.25-9.00$ & .87 \\
\hline & 5 結束力 & .59 & .86 & .78 & .76 & 1 & & & & & & $7.00 \pm 1.41$ & $2.00-9.00$ & .85 \\
\hline & 6 合計得点 & .84 & .95 & .90 & .93 & .88 & 1 & & & & & $7.13 \pm 1.22$ & $2.45-9.00$ & .96 \\
\hline \multirow{4}{*}{$\begin{array}{l}\text { 集 } \\
\text { 団 } \\
\text { 凝 } \\
\text { 集 } \\
\text { 性 }\end{array}$} & 7 ATG-T & .20 & .36 & .34 & .29 & .42 & .32 & 1 & & & & $7.39 \pm 1.42$ & $1.25-9.00$ & .63 \\
\hline & 8 ATG-S & .32 & .47 & .47 & .41 & .44 & .45 & .32 & 1 & & & $7.16 \pm 1.53$ & $1.20-9.00$ & .68 \\
\hline & 9 GI-T & .37 & .56 & .50 & .51 & .57 & .54 & .62 & .53 & 1 & & $6.47 \pm 1.35$ & $1.40-9.00$ & .68 \\
\hline & $10 \mathrm{GI}-\mathrm{S}$ & .29 & .41 & .40 & .43 & .43 & .42 & .23 & .64 & .53 & 1 & $6.51 \pm 1.73$ & $1.50-9.00$ & .82 \\
\hline
\end{tabular}

† Short et al. (2005) の論文中に記載されている Table 8, Table 9 の数值を再構成した.

表 3-c Martínez et al.（2011）で報告されている集合的効力感と集団凝集性の相関行列

\begin{tabular}{|c|c|c|c|c|c|c|c|c|c|c|c|c|c|c|}
\hline & & 1 & 2 & 3 & 4 & 5 & 6 & 7 & 8 & 9 & 10 & $M \pm S D$ & 範囲 & $\alpha$ 係数 \\
\hline \multirow{6}{*}{$\begin{array}{l}\text { 集 } \\
\text { 合 } \\
\text { 的 } \\
\text { 効 } \\
\text { 感 }\end{array}$} & 1 能力 & 1 & & & & & & & & & & $7.25 \pm 1.56$ & - & .88 \\
\hline & 2 努力 & .61 & 1 & & & & & & & & & $7.12 \pm 1.41$ & - & .81 \\
\hline & 3 忍耐力 & .63 & .73 & 1 & & & & & & & & $7.18 \pm 1.42$ & - & .80 \\
\hline & 4 準備力 & .62 & .74 & .61 & 1 & & & & & & & $6.95 \pm 1.59$ & - & .82 \\
\hline & 5 結束力 & .64 & .71 & .67 & .63 & 1 & & & & & & $7.34 \pm 1.45$ & - & .80 \\
\hline & 6 合計得点 & .83 & .88 & .85 & .85 & .85 & 1 & & & & & $7.17 \pm 1.27$ & - & .94 \\
\hline \multirow{4}{*}{$\begin{array}{l}\text { 集 } \\
\text { 団 } \\
\text { 㠜 } \\
\text { 集 } \\
\text { 性 }\end{array}$} & 7 ATG-T & .33 & .35 & .26 & .40 & .41 & .41 & 1 & & & & - & - & .67 \\
\hline & 8 ATG-S & .04 & .11 & .14 & .11 & .23 & .15 & .40 & 1 & & & - & - & .63 \\
\hline & 9 GI-T & .37 & .47 & .38 & .42 & .58 & .52 & .51 & .39 & 1 & & - & - & .73 \\
\hline & $10 \mathrm{GI}-\mathrm{S}$ & .12 & .18 & .18 & .13 & .33 & .22 & .42 & .48 & .58 & 1 & - & - & .70 \\
\hline
\end{tabular}

† Martinez et al. (2011) の論文中に記載されている Table 1, Table 4 の数值を再構成した.

語版スポーツ集合的効力感尺度はスポーツ集団の 集合的効力感を測定する妥当な尺度であると判断 した。

\section{N 考察}

本研究の目的は Short et al. (2005) の作成した スポーツ集合的効力感尺度に対して，近年の集合 
的効力感の測定方法に則った幾つかの修正を加え たうえで，日本語版スポーツ集合的効力感尺度を 作成することであった。さらに, Short et al. （2005）の論文中で報告されている集団凝集性と の相関行列を確認することで構成概念妥当性を検 討することであった。

\section{日本語版スポーツ集合的効力感尺度の因子構造}

本研究では Short et al. (2005) の作成した全20 項目が多次元的な 5 因子を構成する内容的に妥 当な尺度項目であるとの立場から，探索的因子分 析を用いるのではなく，検証的因子分析を用いて 因子構造を検討した，その結果，すべての尺度項 目のパス係数（因子負荷）は $1 \%$ 水準で有意で あり，原版尺度と同様の 5 因子構造を確認し た。ただし，この因子構造に対する適合度指標の 値は一般的に容認される基準値を満たしていなか った（GFI, AGFI, CFIは.90以上，RMSEA に 関しては.06以下).この結果に対して 2 值判断 を求めるのであればこの因子構造は棄却され，基 準值を満たすために因子構造を改善することが求 められる。しかしながら, 内容的妥当性を犠牲に してまで尺度項目を削除し，適合度指標を高める ことに現実的にどれほどの意義があるのか慎重に 考えなければならない（e.g.，南風原，2002）。

本研究では Short et al. (2005) の原版尺度が内容 的妥当性の観点から十分に検討が重ねられている こと, 適合度指標のうち CFI は.93 と基準值を満 たしていること，下位尺度毎の信頼性についても 容認できる值が得られていることを踏まえ, 総合 的に集合的効力感を測定する尺度として十分に使 用できる水準にあると判断した。

今後, 日本語版スポーツ集合的効力感尺度を使 用して研究を行う場合に 5 因子構造の再現性に 関わって留意すべき点が 2 点ある．1つは，日本 語版スポーツ集合的効力感尺度の尺度項目を Podsakoff et al.（2003）の議論に基づき下位尺度 毎に順序立てて配置したが，無作為に配置した場 合の再現性については検討していない点である. これまで, 無作為に配置された提示順序のもとで 邦訳して使用した研究論文（河津ほか，2012；
永尾・杉山，2013；芹澤ほか，2008）では，い ずれも探索的因子分析の結果，原版尺度と同様の 5 因子構造が再現されておらず，尺度項目をいく つか削除したうえで独自の因子構造を報告してい る. もし，日本語版スポーツ集合的効力感尺度の 尺度項目を無作為に配置して使用するのであれ ば，本研究で確認された 5 因子構造が再現され るのかについて改めて検討することが望まれる.

もう 1 つは, 回答形式を従来の 11 件法から 5 件 法に変更した点である.この変更によって尺度の 安定性と正確性が増す（Myers and Feltz, 2007) とされる一方で, Bandura（2006）は11件法の回 答形式の方が微細な変化を捉えられると主張す る。そのため，1つのスポーツ集団の集合的効力 感を経時的に捉えたい場合に 5 件法の回答形式 を使用すると，当該スポーツ集団における集合的 効力感の微細な变化を見逃してしまう可能性があ る. 集合的効力感を測定する尺度は研究目的に応 じて使用することが望まれる（Feltz et al., 2008, pp. 54-57). もし, 集合的効力感の経時的な变化 を捉えることを目的に日本語版スポーツ集合的効 力感尺度の回答形式を変更するのであれば，尺度 項目を無作為に配置した場合と同じく，5因子構 造の再現性について改めて検討することが望まれ る.いずれにせよ，尺度項目を下位尺度毎に提示 し，5件法で回答を求める限りは, 日本語版久 ポーツ集合的効力感尺度の多次元的な 5 因子構 造は十分な信頼性を伴って再現されるものと考え られる注3)。

\section{日本語版スポーツ集合的効力感尺度の構成概念妥 当性}

本研究では日本語版スポーツ集合的効力感尺度 の構成概念妥当性を検討するために集団環境質問 票との相関行列を確認した。その結果，概ね Short et al. (2005) や Martínez et al. (2011)の報 告した相関行列と類似する結果が確認された。し たがって，日本語版スポーツ集合的効力感尺度は スポーツ集団の集合的効力感を測定する妥当な尺 度であると解釈可能であった。ただし, Short et al. (2005) や Martínez et al. (2011) の作成した尺 
度は集団評定法によって集合的効力感を測定する のに対して, 本研究によって作成された尺度は個 人評定法に基づいて集合的効力感を測定するとい う点で明確に区別されなければならない. Short et al.（2002）は，集団評定法と個人評定法による 集合的効力感の測定值の間には統計的に有意な差 が認められるほどの違いはないと報告している. しかしながら，冒頭でも述べたとおり，それぞれ の評定法は依って立つ概念定義が異なっており， 集合的効力感を測定する際の内集団成員の位置づ けが異なる。特に, 近年着目されつつある内集団 成員間に存在する集合的効力感の集団内分散に着 目した“efficacy dispersion” (DeRue et al., 2010; Feltz et al., 2008, pp. 289-291）の検討を行うには,

Bandura（1997）の概念定義に依って立つ個人評 定法の使用が望まれる. 本研究で作成された日本 語版スポーツ集合的効力感尺度を使用して, なぜ 内集団成員間において集団内分散が生じるのか， また集団内分散の程度が集団パフォーマンスに対 してどの程度の説明力を有しているのかといった 点に関する実証研究が今後期待される.

最後に構成概念妥当性を検討するために使用し た集団環境質問票（Carron et al., 1985）につい て述べる、集団環境質問票を使用した実証研究は 海外に打いて相当数存在して抢り，作成されてか ら29年が経過した現在でもなお集団凝集性を測 定する標準的な尺度として使用されている. しか しながら，わが国において Carron et al. (1985) の作成した原版尺度と同様の因子構造が再現され て抢らず広く使用されるに至っていない。本研究 では, 織田ほか（2007）が邦訳した集団環境質 問票を使用した。織田ほか（2007）は Carron et al. (1985）の作成した原版尺度と同様の因子構造 を報告していなかったが，本研究では様々な競技 種目から1244名の調査対象者を収集して検証的 因子分析を行った結果, 細部で注意を要する点 （天井効果や因子負荷が低い尺度項目など）が見 受けられたものの，パス係数（因子負荷）に対す

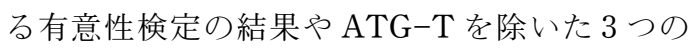
下位尺度の信頼性などを考慮するに，概ね原版尺 度と同様の因子構造が再現されたものと判断可能
であった、今後, 集団凝集性を測定する尺度とし て集団環境質問票を使用した多様な研究が期待さ れる.

\section{謝辞}

質問紙調査の実施にあたり, 各種競技団体の選 手, コーチ, 監督の皆様, 東覀弓先生（大阪国際 大学), 辰見康剛先生 (九州共立大学), 小林未季 代さん, 神谷知里さんをはじめ多くの方にご協力 をいただきました．また，集団環境質問票の使用 にあたっては織田憲嗣様にご助言をいただきまし た.ここに記して感謝申し上げます.

\section{付記}

本研究は JSPS 科研費24700677の助成を受け た。

注

注1）本研究では“collective efficacy” の訳語に「集合 的効力感」を使用する. 概念の提唱者である A. Bandura は “collective efficacy”を個々人に帰属さ れる信念として概念化している (Bandura, 2000). それゆえ, 集団全体の“collective efficacy”は当該 集団の代表值（e.g., 集団内平均值）と分散（ある いは一致）の程度 (e.g., 集団内分散, 級内相関係 数）によって特徵づけられる（Bandura, 1997, p. 479). つまり, 当該集団に所属する個々人の信念 を寄せ集めて構成される集合的 (collective) な効 力感 (efficacy) である. この点を強調する訳語と して「集団効力感」(河津ほか, 2012 ; 永尾 · 杉山, 2013 ; 芹澤ほか，2008）よりも「集合的効力感」 (内田ほか，2011）の方が適切であると判断した. ただし, “collective efficacy”に対してどのような 訳語（集団効力感, 集合効力感) を使用したとし ても, Bandura（1997）の概念定義に基づいて研 究がなされているのであれば同義である.

注2) Myers and Feltz (2007) の概説では“CE-SE method", "CE-CEI method", "CE-CET method", “CE-GCE method” と紹介されている. 本研究で はこれらを順に(1)自己効力感の合算に基づく評定 法, (2)個人評定法, (3)集団評定法, (4)ディスカッ ション評定法と命名した。な拈，“SE”は“selfefficacy”を, “CE”は“collective efficacy”を表 す。まだCE - CEI method”の“I”は “individ- 
ual”を表し，“CE - CET method”の “T”は “Team”を表す。最後の“CE-GCE method”の “G”は“Group”を表す。

注3）実際に使用した質問紙については，紙幅の都合 上掲載できなかった。本研究で使用した質問紙と 同一のレイアウトで研究を行いたい場合は筆頭著 者（uchida@hus.osaka-u.ac.jp）に連絡されたい.

\section{文献}

尼崎光洋 ·清水安夫（2008）高校野球部員を対象とし た集団効力感の研究一集団凝集性及び部活動ストレ ッサーとの関連による検討一. 学校メンタルヘルス, 11: 23-31.

荒井弘和 (2011) 競技者における心理的パフォーマン スに対するコレクティブ・エフィカシーとその関連 要因. 体育学研究, 56: 229-238.

Bandura, A. (1982) Self-efficacy mechanism in human agency. Am. Psychol., 37: 122-147.

Bandura, A. (1997) Self-efficacy: The exercise of control. W. H. Freeman: New York.

Bandura, A. (2000) Exercise of human agency through collective efficacy. Curr. Dir. Psychol. Sci., 9: 75-78.

Bandura, A. (2006) Guide for creating self-efficacy scales. In: Pajares, F. and Urdan, T. (Eds.) Selfefficacy beliefs of adolescents. Information Age Publishing: Connecticut, pp. 307-337.

Carron, A.V., Widmeyer, W.N., and Brawley, L.R. (1985) The development of an instrument to assess cohesion in sport teams: The group environment questionnaire. Int. J. Sport Psychol., 7: 244-266.

DeRue, D.S., Hollenveck, J., Ilgen, D., and Feltz, D.L. (2010) Efficacy dispersion in teams: Moving beyond agreement and aggregation. Person. Psychol, 63: 140 .

Feltz, D.L. and Lirgg, C.D. (1998) Perceived team and player efficacy in hockey. J. Appl. Psychol., 83: 557564.

Feltz, D.L., Short, S.E., and Sullivan, P.J. (2008) Selfefficacy in sport: Research and strategies for working with athletes, teams and coaches. Human Kinetics: Champaign.

淵上克義·今井奈緒·西山久子・鎌田雅史（2006）集 団効力感に関する理論的 · 実証的研究一文献展望, 学級集団的効力感, 教師集団効力感作成の試み一. 岡山大学教育学部研究集録, 131: 141-153.

Gully, S.M., Incalcaterra, K.A., Joshi, A., and Beaubi- an, J.M. (2002) A meta-analysis of team-efficacy, potency and performance: Interdependence and level of analysis as moderators of observed relationships. J. Appl. Psychol., 87: 819-832.

南風原朝和（2002）モデル適合度の目標適合度一観測 変数の数を減らすことの是非を中心に一. 行動計量 学, 29: 160-166.

芳地泰幸 · 中山貴太 · 山田泰行 · 水野基樹（2010）日 本の大学生スポーツチームに打りる CEQS の有効性 に関する研究. 日本スポーツ心理学会第37回大会研究 発表抄録集, pp. 114-115.

本郷由紀子（2005）中学生における学級の集団効力感 尺度の作成と自己効力感および学校適応感の関連に ついて. 滋賀大学大学院教育学研究科論文集, 8: 6372 .

本間道子 · 草野敦子 ·千葉朋子 (2004) 集団成果に影 響を及ぼす集合効力感の効果一スポーツチームを対 象に一. 日本女子大学紀要人間社会学部，15: 41-57. 池田英治 · 内山治樹 (2012) Collective Efficacy 理論に よるチーム・パフォーマンス向上の試み：バスケッ トボール競技を対象に。体育学研究，57: 663-682.

河津慶太・杉山佳生・中須賀巧 (2012) スポーツチー ムにおける集団効力感とチームパフォーマンスの関 係の種目間検討. スポーツ心理学研究, 39: 153-167.

Martínez, J.R., Guillén, F., and Feltz, D.L. (2011) Psychometric properties of the spanish version of the collective efficacy questionnaire for sports. Psicothema, 23: 503-509.

Myers, N.D. and Feltz, D.L. (2007) From self-efficacy to collective efficacy in sport: Transitional methodological issues. In: Tenenbaum, G. and Eklund, R. (Eds.) Handbook of sport psychology (3rd ed.). John Wiley \& Sons: New Jersey, pp. 799-819.

永尾雄一・杉山佳生（2013）日本版スポーツ集団効力 感尺度の作成. 九州体育. スポーツ学研究, 27(2): $1-11$.

永尾雄一 ·杉山佳生 · 山崎将幸 · 河津慶太（2007）日 本版スポーツ集団効力感尺度 $(\mathrm{J}-\mathrm{CEQS})$ 開発の試み. 日本スポーツ心理学会第34回大会研究発表抄録集, pp. $156-157$.

織田憲嗣 · 山本勝昭・徳永幹雄 (2007) スポーツにお ける集団凝集性の構造検証ならびにパフォーマンス との関係. 財団法人ミズノスポーツ振興会スポーツ 医科学研究助成報告書.

Podsakoff, P.M., MacKenzie, S.M., Lee, J., and Podsakoff, N.P. (2003) Common method variance in behavioral research: A critical review of the literature 
and recommended remedies. J. Appl. Psychol, 88: 879-903.

芹澤啓美 · 尼崎光洋 ·清水安夫（2008）高校運動部員 に抢ける集団効力感に関する研究—集団効力と部活 動適応及び社会的スキルとの関係一. 神奈川体育学 会機関誌体育研究, 41: 17-22.

Short, S.E., Apostal, K., Harris, C., Poltavski, D., Young, J., Zostautas, N., Sullivan, P., and Feltz, D.L. (2002) Assessing collective efficacy: A comparison of two approaches. J. Sport Exerc. Psychol., 24: 115116.

Short, S.E., Sullivan, P., and Feltz, D.L. (2005) Development and preliminary validation of the collective efficacy questionnaire for sports. Meas. Phys. Educ. Exerc. Sci., 9: 181-202.

高口央 ·坂田桐子（2004）学生サークル集団に抢ける
集団効力感尺度の作成. 日本グループ・ダイナミッ クス学会第51回大会発表論文集, pp. 176-177.

内田遼介 · 土屋裕睦 - 菅生貴之 (2011) スポーツ集団 を対象とした集合的効力感研究の現状と今後の展 望 : パフォーマンスとの関連性ならびに分析方法に 着目して. 体育学研究, 56: 491-506.

Widmeyer, W.N., Brawley, L.R., and Carron, A.V. (1985) The measurement of cohesion in sport teams: The group environment questionnaire. Sport Dynamics: Ontario, pp. 89-91.

Zaccaro, S., Blair, V., Peterson, C., and Zazanis, M. (1995) Collective efficacy. In: Maddux, J.E. (Ed.) Self-efficacy, adaptation, and adjustment: Theory, research, and application. Plenum Press: New York, pp. 305-327. 


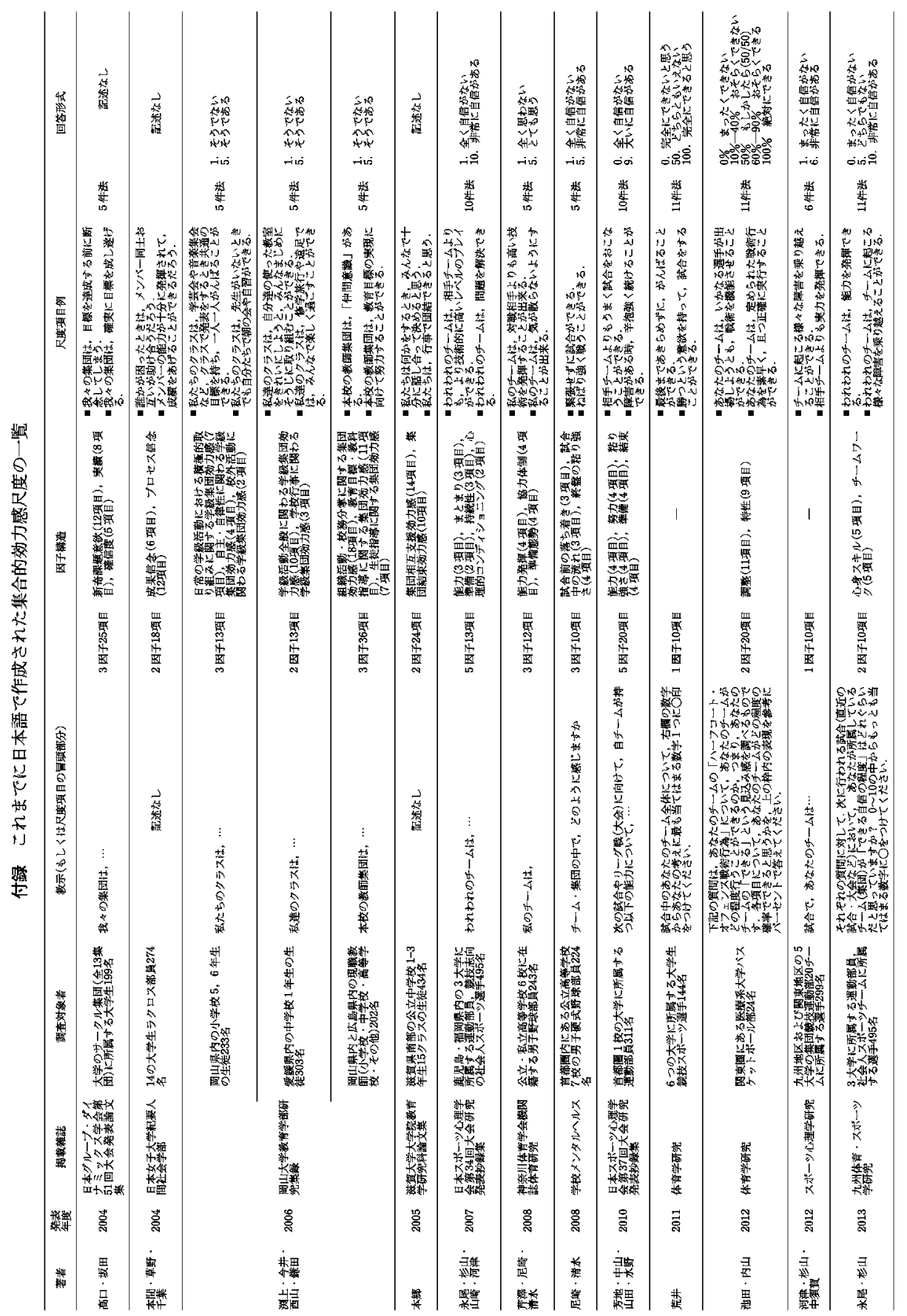

(平成 25 年 10 月 30 日受付

平成26年 6 月 18 日受理

Advance Publication by J-STAGE

Published online 2014/8/11 